\title{
PENGEMBANGAN MODEL SISTEM E-COMMERCE BERBASIS WEB DENGAN CONTENT MANAGEMENT SYSTEM (CMS)
}

\author{
Rizka Pitriyani ${ }^{1}$, Gandung Triyono ${ }^{2 *}$, Sudiyatno Yudi Nugroho ${ }^{3}$ \\ ${ }^{12}$ Fakultas Teknologi Informasi, Program Studi Sistem Informasi, Universitas Budi Luhur, Jakarta, Indonesia \\ ${ }^{3}$ Fakultas Ekonomi dan Bisnis, Program Studi Manajemen, Universitas Budi Luhur, Jakarta, Indonesia \\ Email: ${ }^{1} 1612510014 @ s t u d e n t . b u d i l u h u r . a c . i d,{ }^{2 *}$ Gandung.triyono@budiluhur.ac.id, sudiyatno.yudinugroho@budiluhur.ac.id \\ (* : coressponding author)
}

\begin{abstract}
Abstrak-Pembatasan Sosial Berskala Besar (PSBB) merupakan peraturan yang diterapkan oleh pemerintah dalam rangka mencegah penyebaran virus covid-19. PSBB adalah pembatasan kegiatan tertentu penduduk dalam suatu wilayah yang diduga terinfeksi corona virus disease 2019 (Covid-19) sedemikian rupa untuk mencegah kemungkinan penyebarannya. Penerapan PSBB yang ketat berpengaruh yang serius terhadap dunia usaha, salah satunya adalah pelaku usaha konveksi. Salah satunya yang kena dampaknya adalah toko-toko konveksi yang proses transaksinya masih manual, yaitu mengandalkan pembeli datang langsung ke toko. Permasalahan tersebut masih dirasakan sampai sekarang. Oleh sebab itu, penelitian ini mencoba menyelesaikan masalah tersebut dengan pengembangan model sistem e-commerce berbasis web untuk meningkatkan penjualan. Model sistem e-commerce berbasis web dikembangkan dengan menggunakan Content Management System (CMS) dan Business Model Canvas (BMS). CMS digunakan untuk mengembangkan model sistem e-commerce berbasis web dan BMS digunakan untuk menganalisis sistem berjalan dan mengidenfitikasi kebutuhan sistem. Model sistem e-commerce ini telah diujikan pada toko Asri Konveksi Collection. Hasil pengujiannya adalah mendapatkan model sistem $e$ commerce yang sesuai dengan kebutuhan toko Asri Konveksi Collection. Model sistem e-commerce berbasis web yang dikembangkan telah diuji langsung ke user, hasil pengujian yang didapatkan adalah cukup bagus.
\end{abstract}

Kata Kunci: e-commerce, CMS, pemodelan, pemodelan sistem, perancangan sistem

Abstract-Pembatasan Sosial Berskala Besar (PSBB) are regulations implemented by the government to prevent the spread of the Covid-19 virus. PSBB is a restriction on specific activities of residents in an area suspected of being infected with the Coronavirus disease 2019 (Covid-19) in such a way as to prevent its possible spread. The implementation of PSBB has a severe effect on the business world, one of which is the convection business actors. One affected was the convection shops whose transaction processes were still manual, namely buyers who went directly to the shop. This problem is still in effect today. Therefore this, study resolves the problem by developing a web-based e-commerce system model to increase sales. The web-based e-commerce model system developed using Content Management System (CMS) and Business Model Canvas (BMS). CMS is used to create a web-based e-commerce system model and BMS to analyze the system being run and identify the system's requirements. This e-commerce system model has tested at the Asri Konveksi Collection convection shop. The result is to get an e-commerce system model that suits the needs of Asri Konveksi Collection stores. The web-based ecommerce system model developed has been tested directly on the users, and the test results are quite good.

Keywords: e-commerce, CMS, modeling, system modeling, system design

\section{PENDAHULUAN}

Pembatasan Sosial Berskala Besar (PSBB) merupakan peraturan yang diterapkan oleh pemerintah dalam rangka mencegah penyebaran virus covid-19. PSBB adalah pembatasan kegiatan tertentu penduduk dalam suatu wilayah yang diduga terinfeksi corona virus disease 2019 (Covid-19) sedemikian rupa untuk mencegah kemungkinan penyebarannya. Penerapan PSBB yang ketat berpengaruh yang serius terhadap dunia usaha, salah satunya adalah pelaku usaha konveksi. Salah satunya yang kena dampaknya adalah toko-toko konveksi yang proses transaksinya masih konvensional, yaitu mengandalkan pembeli datang langsung ke toko. Permasalahan tersebut masih dirasakan sampai sekarang.

Pembatasan kegiatan masyarakat berpengaruh langsung pada sektor perdagangan, yang berimbas pada perekonomian [1]. Penerapan PSBB sangat mempengaruhi sektor bisnis khususnya penjualan dan pemasaran, salah satu toko yang terkena dapak dari pandemi ini adalah toko Asri Konveksi Collection. Toko ini selain menjual secara konvensional juga telah mencoba untuk penjualan secara dengan media sosial, yaitu Instagram dan WhatsApp. Produk yang dijual adalah kaos dan masker kain. Kaos dan masker kain yang dijual merupakan produksi sendiri. Penjualan melalui Instagram dan WhatsApp mempunyai keterbatasan yaitu sulitnya memasarkan produk yang lebih luas, selain itu sulitnya update informasi produk-produk baru.

Dengan adanya PSBB ini budaya masyarakat telah banyak berubah, salah satunya adalah berbelanja secara online. Menurut CNN Indonesia kenaikan transaksi secara online mencapai $400 \%$. Hal ini mengakibatkan pertumbuhan e-commerce dengan pesat. E-commerce merupakan salah satu teknologi informasi yang digunakan untuk menunjang proses perdagangan. E-commerce memungkinkan semua transaksi dilakukan secara daring. 
Oleh sebab itu, penelitian ini mencoba untuk menyelesaikan beberapa masalah pada toko Asri Konveksi Collection dengan mengembangkan model sistem e-commerce berbasis web.

Beberapa penelitian telah mencoba menyelesaikan masalah dengan mengembangkan model sistem $e$ commerce, seperti penelitian [2]-[5]. Penelitian yang dilakukan oleh [2] dan [3], telah menyelesaikan masalah pada toko konveksi dengan pengembangan model sistem e-commerce berbasis web. Penelitian [4] mengembangkan e-commerce untuk memperluas jangkauan pasar Pada Toko Batik Marissa. Tujuan utama dari penelitian ini adalah untuk memperluas jangkauan pelanggan, target jangkauannya adalah seluruh Indonesia. Penelitian [5] mengembangkan e-commerce untuk menyelesaikan masalah pada Toko Chipindwear. Masalah tersebut adalah sulitnya meningkatkan penjualan, karena penjualan yang dilakukan pada toko tersebut masih konvensional. Dari beberapa penelitian tersebut tersebut, model yang dikembangkan belum sampai tahap pengujian ke user. Hal ini yang menjadi tantangan pada penelitian ini untuk mengembangkan model sistem $e$ commerce berbasis web yang telah diuji ke user atau sudah sampai dengan implementasinya.

Berdasarkan masalah dan penelitian sebelumnya, maka penelitian ini bertujuan mengembangkan model sistem e-commerce berbasis web yang sesuai dengan kebutuhan user. Model sistem e-commerce berbasis web yang dihasilkan diharapkan dapat meningkatkan penjualan pada Asri Konveksi Collection. Pengembangan model digunakan framework Content Management System (CMS) Wordpress. Dalam mengidentifikasi kebutuhan model e-commerce digunakan BMC. Model sistem e-commerce yang dikembangkan telah diuji ke user dan telah diimplementasikan pada laman https://asrikonveksi.com. Laman tersebut telah dilakukan optimasi dengan Search Engine Optimization (SEO) untuk mempercepat proses pengenalan toko ke masyarakat luas. Hasil pengujian model yang dilakukan mendapatkan sambutan yang baik oleh user. Pengujian yang dilakukan dengan cara mengimplementasikan model yang dikembangkan dan dimintakan pendapat ke user.

\section{METODE PENELITIAN}

E-Commerce merupakan kegiatan perdagangan yang dilakukan secara elektronik, yang meliputi proses penyebaran, pembelian, penjualan, pemasaran barang dan jasa melalui sistem elektronik. Sistem elektronik seperti internet, televisi, atau jaringan komputer lainnya [6]. Keunggulan dari e-commerce adalah dapat menjangkau pelanggan lebih luas, penghematan biaya operasional. Selain itu, konsumen dapat memiliki lebih banyak pilihan barang dan jasa dengan akses penuh selama 24 jam. Konsumen juga bisa diuntungkan dengan adanya perbandingan harga secara langsung [7]. Menurut [8], komponen-komponen pada e-commerce adalah konsumen, penjual, produk, infrastruktur, frontend, backend, dan partner.

Konsumen merupakan pengguna internet yang menjadi target pasar yang potensial untuk diberikan berbagai macam penawaran baik berupa produk, jasa, maupun informasi oleh penjual. Penjual adalah pihak yang menawarkan produk, jasa atau informasi kepada para konsumen baik secara individu maupun organisasi. Produk merupakan barang atau jasa yang ditawarkan dalam bentuk digital karena konsumen tidak melihat secara langsung dalam bentuk fisik. Infrastruktur meliputi penggunaan perangkat keras, perangkat lunak, dan juga sistem jaringan komputer seperti penggunaan jaringan komunikasi internet. Frontend merupakan bagian antarmuka website yang berinteraksi langsung dengan user atau pengguna. Backend adalah bagian tampilan layar untuk admin website yang menjadi pusat proses pengaturan yang secara tidak langsung berperan sebagai pendukung antarmuka pada frontend. Partner bisnis adalah pihak yang akan melakukan kerjasama ataupun kolaborasi dengan para produsen. Contoh dari partner bisnis ini misalnya seperti bank yang melakukan kerjasama dengan pihak ketiga penyedia payment gateway yang memudahkan konsumen melakukan pembayaran baik melalui transfer ataupun mobile banking.

Menurut [9] terdapat beberapa jenis e-commerce, yaitu Business to Business (B2B), Business to Customer (B2C), Customer to Business (C2B), Customer to Customer (C2C), Business to Government (B2G) dan Government to Customer (G2C). B2B merupakan transaksi bisnis antara pelaku bisnis dengan pelaku bisnis lainnya. Dapat berupa kesepakatan spesifik yang mengandung kelancaran bisnis. B2C merupakan transaksi bisnis dan aktivitas yang dilakukan produsen kepada konsumen secara langsung. C2B adalah model bisnis di mana konsumen atau individu menciptakan nilai dan perusahaan mengkonsumsi nilai akan proses bisnis. C2C merupakan aktivitas bisnis (penjualan) yang dilakukan oleh individu (konsumen) kepada individu (konsumen) lainnya. B2G merupakan turunan dari B2B, perbedaannya proses ini terjadi antara pelaku bisnis dan instansi pemerintah. G2C merupakan hubungan atau interaksi antara pemerintah dan masyarakat. Konsumen dalam hal ini masyarakat, dapat dengan mudah menjangkau pemerintah sehingga memperoleh kemudahan dalam pelayanan sehari-hari.

Pada penelitian ini, model sistem e-commerce yang dikembangkan merupakan pengembangan dari jenis model B2C. Guna memperlancar pengembangan model sistem e-commerce berbasis web dengan jenis B2C, maka dibuat tahapan penelitian atau metodologi. Tahapan penelitian yang digunakan dituangkan dalam bentuk diagram, lihat Gambar 1. 


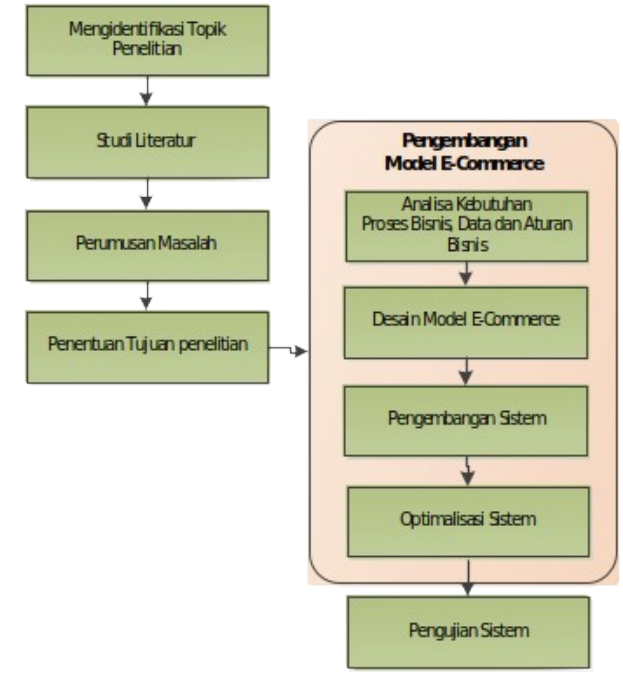

Gambar 1. Metodologi pengembangan mode sistem e-commerce berbasis web

Pada Gambar 1 diperlihatkan bahwa setelah melakukan penentuan masalah dan tujuan penelitian maka tahapan penelitian yang dilakukan adalah:

\subsection{Analisis Kebutuhan}

Pada tanap ini dilakukan analisis kebutuhan untuk pengembangan model sistem e-commerce, kegiatan ini meliputi analisis proses sistem berjalan, data dan aturan bisnis yang berlaku di perusahaan. Dalam proses analisis kebutuhan menggunakan model BMC. BMC merupakan kerangka kerja yang banyak digunakan untuk mendefinisikan model bisnis startup. BMC disusun dengan tujuan untuk menjelaskan, menilai, memvisualisasikan, serta mengubah model bisnis sehingga kinerja yang dihasilkan oleh startup lebih maksimal. Model bisnis ini bisa diterapkan oleh semua jenis startup tanpa terbatas sektor usaha [10].

Menurut [10], BMC dapat menjelaskan hubungan sembilan elemen model bisnis yang digambarkan secara visual. Penggambaran secara visual ini bertujuan agar inovasi yang dibuat pada model bisnis lebih mudah dipahami dan dimengerti. Pada model BMC harus dapat memberikan sembilan elemen, yaitu value proposition, customer segments, channels, customer relationship, key activities, key resources, key partnership, revenue stream dan cost structure. Value Proposition mencakup produk atau layanan apa yang ditawarkan untuk calon customer, ini merupakan elemen yang sangat penting. Customer segments menjadi blok area yang paling utama karena dari pelanggan-lah kita akan mendapatkan pemasukan. Channels merupakan sarana untuk menyampaikan nilai atau manfaat dari produk kepada customer segment. Di dalam lingkup ini yang dinilai adalah bagaimana menjalin hubungan dengan pelanggan. Agar pelanggan tidak mudah berpaling ke bisnis yang lain, maka sangat penting untuk menjalin hubungan yang baik. Selain itu, diperlukan juga pengawasan yang ketat dan intensif. Key activities mencakup segala aktivitas yang harus dilakukan seorang pelaku bisnis untuk menghasilkan produk atau layanan yang baik dan memuaskan. Key Resources adalah berbagai sumber daya yang dimiliki pebisnis atau organisasi untuk mewujudkan proposisi nilai seperti manusia, brand, peralatan, dan teknologi. Key Partnership berisi pihak-pihak yang menjadi penentu terhadap jalannya suatu bisnis. Revenue stream mencakup langkahlangkah yang harus dikuasai oleh seorang pebisnis. Seperti pemanfaatan biaya iklan, langganan, penjualan retail, lisensi, dan sebagainya. Cost structure merupakan biaya-biaya apa saja yang harus dikeluarkan untuk membentuk, memproduksi dan memasarkan produk atau layanan bisnis.

\subsection{Desain Model E-Commerce}

Bedasarkan hasil indentifikasi kebutuhan dengan BMC, maka langkah berikutnya adalah desain model sistem e-commerce. Model dikembangkan dengan Unified Modeling Language (UML). Menurut [11], UML merupakan bahasa standar yang dapat digunakan untuk analisis dan desain berbasis object oriented. UML memiliki sembilan diagram yang paling umum digunakan untuk pemodelan, yaitu use case diagram, activity diagram, class diagram, sequence diagram, state machine diagram, communication diagram, deployment diagram, component diagram dan package diagram. 
Use case diagram yaitu salah satu jenis diagram pada UML yang menggambarkan interaksi antara sistem dan aktor, use case diagram juga dapat men-deskripsikan tipe interaksi antara si pemakai sistem dengan sistemnya. Activity diagram atau diagram aktivitas yaitu salah satu jenis diagram pada UML yang dapat memodelkan proses-proses apa saja yang terjadi pada sistem. Sequence diagram yaitu salah satu jenis diagram pada UML yang menjelaskan interaksi objek yang berdasarkan urutan waktu, sequence diagram juga dapat menggambarkan urutan atau tahapan yang harus dilakukan untuk dapat menghasilkan sesuatu seperti pada use case diagram. Class diagram yaitu salah satu jenis diagram pada UML yang digunakan untuk menampilkan kelas-kelas maupun paket-paket yang ada pada suatu sistem yang nantinya akan digunakan. Jadi diagram ini dapat memberikan sebuah gambaran mengenai sistem maupun relasi-relasi yang terdapat pada sistem tersebut. Statemachine diagram yaitu salah satu jenis diagram pada UML yang menggambarkan transisi maupun perubahan keadaan suatu objek pada sistem. Communication diagram yaitu salah satu jenis diagram pada UML yang dapat menggamabarkan tahapan terjadinya suatu aktivitas dan diagram ini juga menggambarkan interaksi antara objek yang ada pada sistem. Hampir sama seperti sequence diagram akan tetapi communication diagram lebih menekankan kepada peranan masing-masing objek pada sistem. Deployment diagram yaitu salah satu diagram pada UML yang menunjukan tata letak suatu sistem secara fisik, dapat juga dikatakan untuk menampilkan bagian-bagian software yang terdapat pada hardware dan digunakan untuk menerapkan suatu sistem dan hubungan antara komponen hardware. Jadi Deployment diagram intinya untuk menunjukan letak software pada hardware yang digunakan sistem. Component diagram yaitu salah satu jenis diagram pada UML yang menggambarkan software pada suatu sistem. Component diagram merupakan penerapan software dari satu ataupun lebih class, dan biasanya berupa file data atau .exe, source kode, tabel, dokumen dsb.Package diagram yaitu salah satu jenis diagram pada UML digunakan untuk mengelompokan kelas dan juga menunjukan bagaimana elemen model akan disusun serta mengambarkan ketergantungan antara paket-paket [11].

Dalam penelitian ini hanya akan menggunakan dua diagram yaitu Use Cace Diagram dan Class Diagram. Use case diagram akan digunakan untuk memperlihatkan atau menvisualisasi fungsi-fungsi yang ada pada model. Dan untuk class diagram digunakan untuk memvisualisasikan model data yang digunakan.

\subsection{Pengembangan Sistem}

Hasil desain mode sistem e-commerce digunakan untuk pengembangan sistem. Sistem e-commerce dikembangkan dengan framework Content Management System (CMS). CMS merupakan aplikasi berbasis web yang digunakan untuk mengatur konten website, hampir semua website memiliki CMS yang mengatur kontennya, kecuali website statis. Sebuah CMS biasanya memiliki kemampuan untuk meng-update artikel, mengedit halaman website, mengatur menu, dan tampilan website. Beberapa macam CMS yang sering digunakan untuk pengembangan sistem seperti WordPress, Joomla, Drupal, Aura, OpenCart, Prestashop, Moodle dan vBulletin. CMS WordPress, OpenCart dan Joomla merupakan CMS yang sering digunakan untuk pengembangan e-commerce. Pada penelitian ini menggunakan Wordpress untuk pengembangan sistem $e$ commerce berbasis web [12].

Pengembangan sistem e-commerce pada penelitian ini dilakukan dengan empat tahapan, yaitu:

a. Tentukan tujuan pembuatan website, pada tahap ini sudah dijelaskan dari awal bahwa ingin mengembangkan model sistem e-commerce. Model yang dikembangkan sesuai dengan desain yang terbentuk pada tahap sebelumnya.

b. Tentukan platform website. Pada pengembangan sistem e-commer ini adalah menggunakan CMS. Pada penelitian ini akan menggunakan CMS WordPress.

c. Register hosting dan nama domain. Pada langkah ini adalah memilih hosting terbaik.

d. Instalasi dan Pengaturan Website. Setelah membeli hosting dan domain, maka proses selanjutnya adalah melakukan instalasi dan setting website. Beberapa hal yang perlu dilakukan instalasi, yaitu instal sertifikat SSL, instal wordpress dan pengaturan website.

\subsection{Optimalisasi Sistem}

Setelah model selesai dikembangkan dan pengujian, tahap terakhir dari pengembangan ini adalah mmplementasikan model sistem e-commerce. Implementasi dari model sistem e-commerce ini dilakukan pada laman https://asrikonveksi.com. Setelah berhasil diimplementasikan pada website, maka tahap selanjutnya adalah mengoptimalkan kinerja dari website itu sendiri. Pengoptimalan website ini menggunakan pendekatan SEO. SEO merupakan kependekan dari Search Engine Optimization. SEO merupakan sekumpulan strategi untuk meningkatkan keberadaan dan visibilitas sebuah website di halaman hasil mesin pencari atau Search Engine Result Page (SERP). Semakin tinggi posisi dan semakin banyak sebuah situs muncul di halaman hasil mesin pencari, maka akan makin banyak pengunjung yang datang melalui mesin pencari tersebut. Pentingnya SEO 
available online at http://jom.fti.budiluhur.ac.id/index.php/IDEALIS/index

didasari oleh fakta bahwa banyak situs yang memperoleh mayoritas kedatangan pengunjung atau web traffic-nya melalui hasil organik yang didapatkan dari mesin pencari [13].

\subsection{Pengujian Sistem}

Pengujian yang dilakukan adalah menggunakan teknik blackbox testing dan pengujian ke user. Blackbox testing dilakukan pada saat pengembangan sistem. Blackbox testing dilakukan dihadapan user, yaitu menguji fungsi pada model e-commerce yang ada. Pengujian ini menggunakan dokumen atau data dari lapangan. Kemudian, pengujian pada user merupakan penilaian model yang dilakukan oleh user. Pengujian ini dilakukan setelah setelah model sistem e-commerce diterapkan di laman web https://asrikonveksi.com.

\section{HASIL DAN PEMBAHASAN}

\subsection{Hasil Analisis}

Model BMC yang dihasilkan dari wawancara dan pengamatan di lapangan dapat dilihat pada Gambar 2. Kesembilan elemen telah didapatkan hasil yang cukup baik untuk pengembangan model e-commerce, mulai dari elemen customer segments sampai dengan revenue streams.

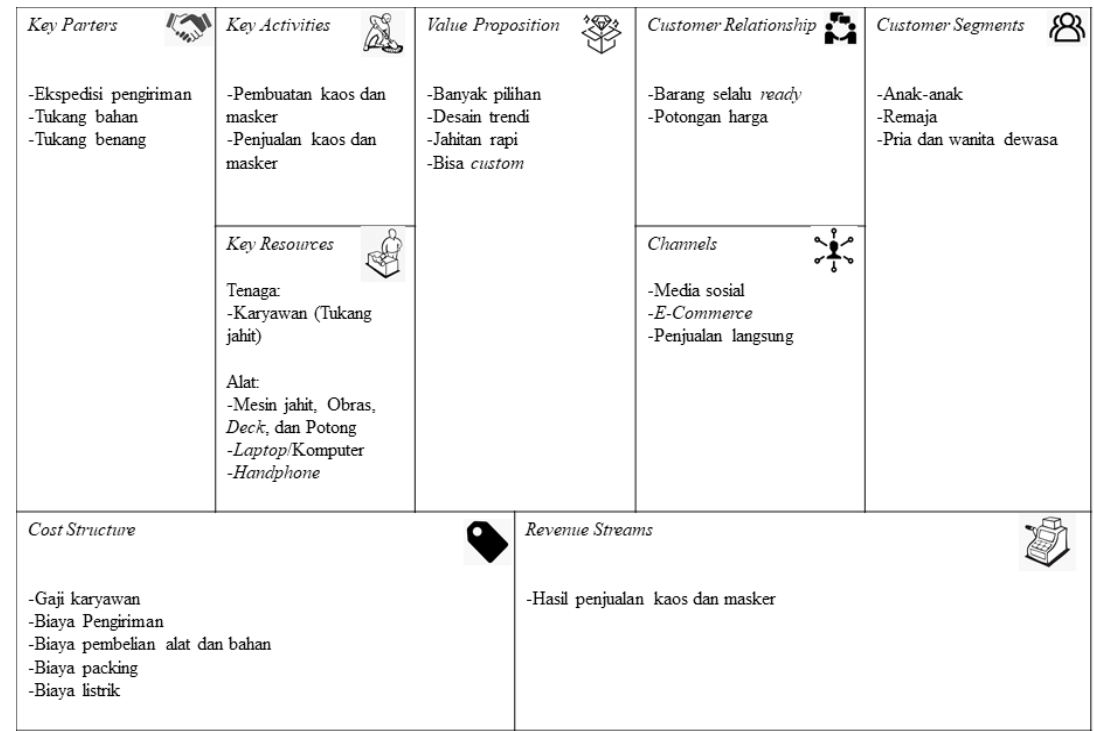

Gambar 2. Hasil analisis dengan BMC

Berikut ini adalah penjelasan dari elemen-elemen Business Model Canvas (BMC) pada Gambar 2:

a. Customer Segments, merupakan pembeli dari Asri Konveksi Collection, yaitu kalangan anak-anak, remaja, pria atau wanita dewasa, toko kaos/masker, dan pedagang kaos/masker.

b. Value Proposition, disebut juga nilai yang ditawarkan oleh Asri Konveksi Collection pada usaha bisnisnya, yaitu banyak pilihan baik warna maupun model, desain trendi (gaya modern), jahitan rapi, bisa custom (pemesanan sesuai keinginan customer), menyerap keringat, nyaman dipakai, dan ketepatan waktu.

c. Channels Channels, merupakan sarana yang digunakan oleh Asri Konveksi Collection pada usaha konveksinya, yaitu melalui media sosial (Instagram dan WhatsApp), e-commerce (web dengan wordpress), dan penjualan secara langsung dari rumah.

d. Key Partners, merupakan pihak yang berkaitan dengan Asri Konveksi Collection dalam menjalankan usahanya, yaitu dengan para ekspedisi pengiriman (JNE), tukang bahan, dan tukang benang.

e. Key Activities, merupakan kegiatan yang dilakukan oleh Asri Konveksi Collection untuk menjalankan usahanya, yaitu pembuatan desain, pembuatan produk custom, dan mencari model terbaru agar selalu trendi.

f. Key Resources, merupakan komponen yang dibutuhkan oleh Asri Konveksi Collection untuk menjalankan usaha konveksinya, yaitu tenaga ahli berupa karyawan/tukang jahit yang dapat menjahit dengan rapi agar tidak mengecewakan para pelanggan, memiliki konveksi, dan memiliki karyawan yang dapat membuat desain. Alat yang dibutuhkan untuk proses pembuatan kaos dan masker, yaitu mesin jahit, mesin obras untuk membuat jahitan yang rapi pada tepi kaos, mesin deck untuk membuat lipatan yang rapi pada tepi kaos, dan mesin potong untuk memotong bahan sesuai pola yang telah ditentukan. 
g. Cost Structures, merupakan seluruh biaya yang dikeluarkan oleh Asri Konveksi Collection dari awal produksi sampai akhir ke tangan pelanggan, yaitu gaji karyawan/tukang jahit, biaya pengiriman, biaya packing, biaya listrik, serta biaya pembelian alat dan bahan.

h. Customer Relationship, merupakan cara menjalin hubungan dengan para pelanggan yang dilakukan oleh Asri Konveksi Collection, yaitu dengan cara barang yang diinginkan oleh pelanggan harus selalu ready, harga lebih murah jika pembelian lebih banyak biasanya dalam satuan lusin (mendapatkan potongan harga).

i. Revenue Streams, merupakan komponen yang dilakukan oleh Asri Konveksi Collection untuk menghasilkan uang, yaitu dengan cara menjual kaos dan masker yang diproduksi sendiri.

\subsection{Model Sistem E-Commerce}

Model sistem e-commerce berbasis web didesain dengan menggunakan diagaram UML. Model yang dihasilkan diperlihatkan menggunakan use case diagram. Pada model sistem e-commerce yang dikembangkan memiliki beberapa fungsi utama, yaitu Use Case Login, Use Case Master, Use Case Transaksi dan Use Case Pembuatan Laporan. Diagram use case yang dihasilkan dapat dilihat pada Gambar 3, 4, 5 dan 6.

a. Use Case Diagram

Use case pertama yang dibuat adalah use case Login dan use case Logout. Use case ini berfungsi sebagai privasi dan keamanan terhadap user yang menggunakan. User yang menggunakan adalah karyawan di toko Asri Konveksi Collection dan pelanggan. Karyawan dan pelanggan yang menggunakan fungsi ini disebut Aktor dalam pemodelan use case diagram. Diagram ini dapat dilihat pada Gambar 3.

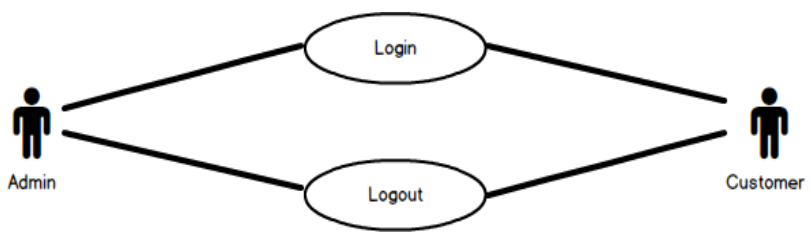

Gambar 3. Use Case Diagram Login dan Logout

Use Case Master memiliki dua fungsi utama, yaitu untuk pengelolaan produk dan customer. Fungsi dari pengelolaan produk adalah menambah, mengubah dan menghapus produk-produk yang ada. Sedangkan, fungsi pengelolaan customer atau pelanggan adalah fungsi untuk melakukan registrasi calon pelanggan baru dan mengubah data pelanggan yang terdaftar. Fungsi-fungsi ini dapat dilihat pada Gambar 4.
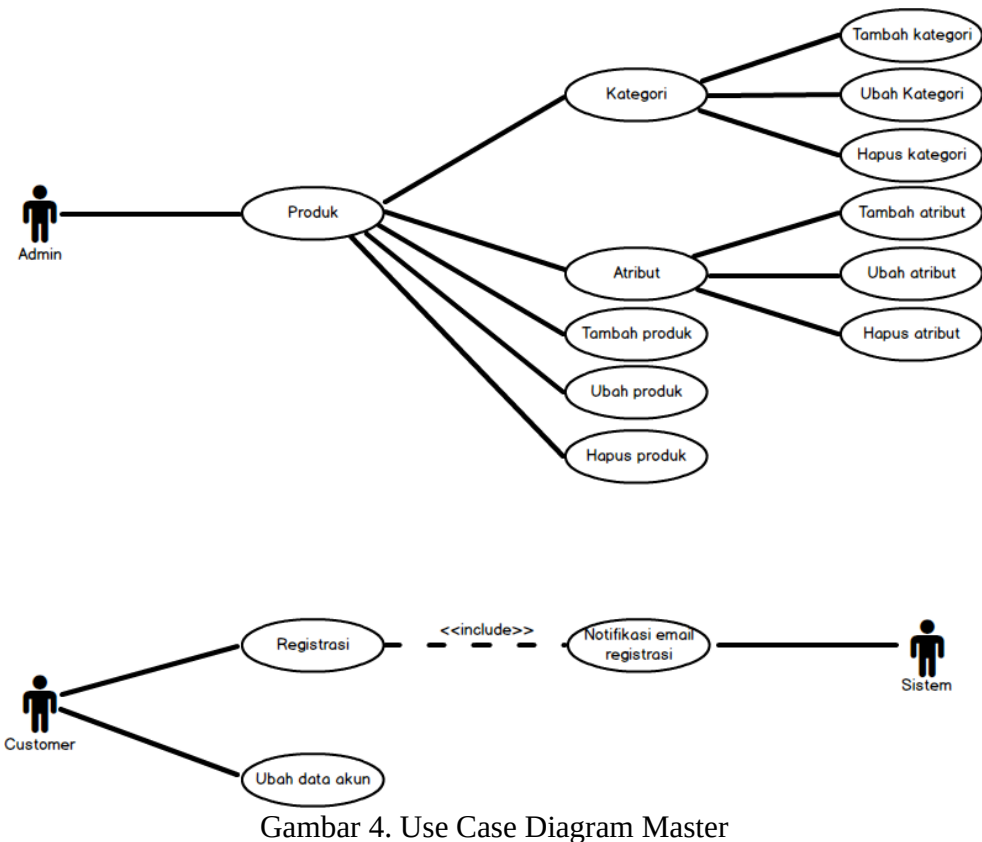

Pada Gambar 5 merupakan use case Transaksi. Use Case Transaksi merupakan fungsi-fungsi utama dalam mendukung proses pemasaran, pemesanan, pengiriman dan pembayaran. Pada use case transaksi dapat 
digunakan oleh pelanggan untuk melihat produk yang ada, pemesanan produk dan pembayaran produk. Kemudian pada sisi karyawan atau admin dapat digunakan untuk memverifikasi hasil pemesanan dan pembayaran produk. Selain itu, admin juga dapat memberitahukan atau notifikasi kepada pelanggan melalui email mengenai produk yang dipesan.
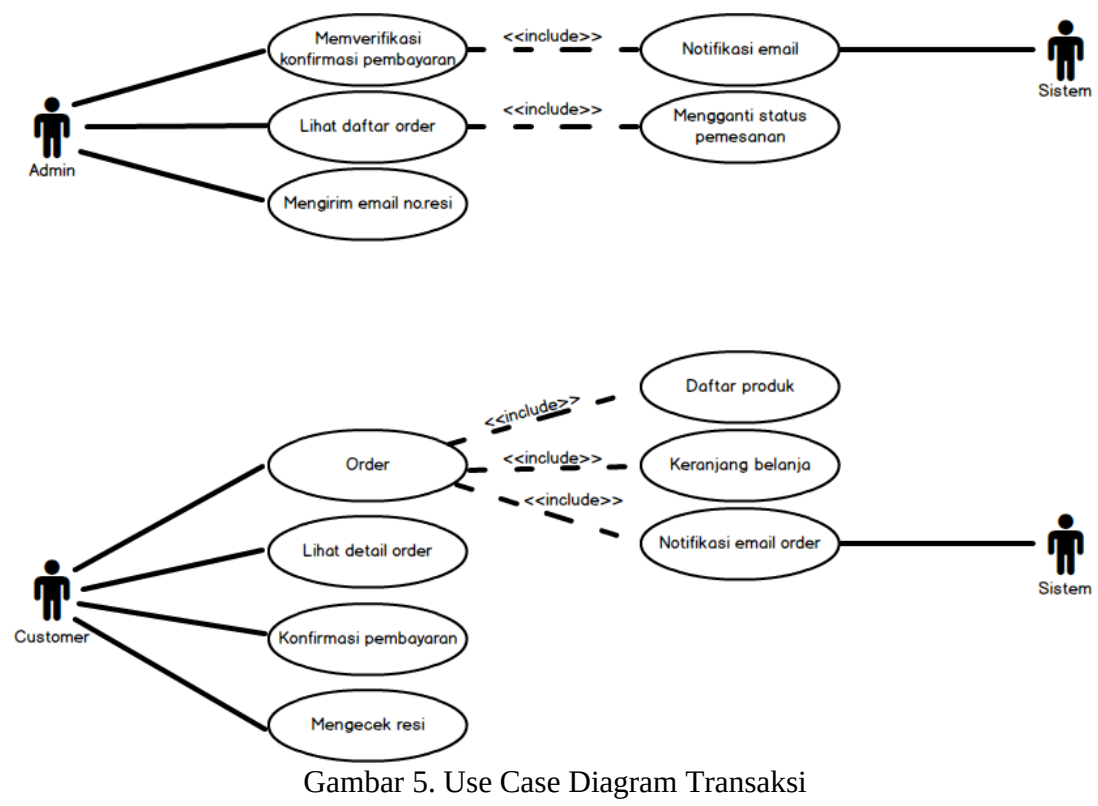

Use Case Diagram Pembuatan Laporan merupakan fungsi untuk mencetak laporan yang dibutuhkan pihak manajemen. Fungsi-fungsi ini dapat dijalankan oleh aktor Admin atau Karyawan dari toko Arsi Konveksi Collection. Use case diagram Laporan ini dapat digunakan oleh manajemen untuk mengevaluasi hasil penjualan yang dilakukan.

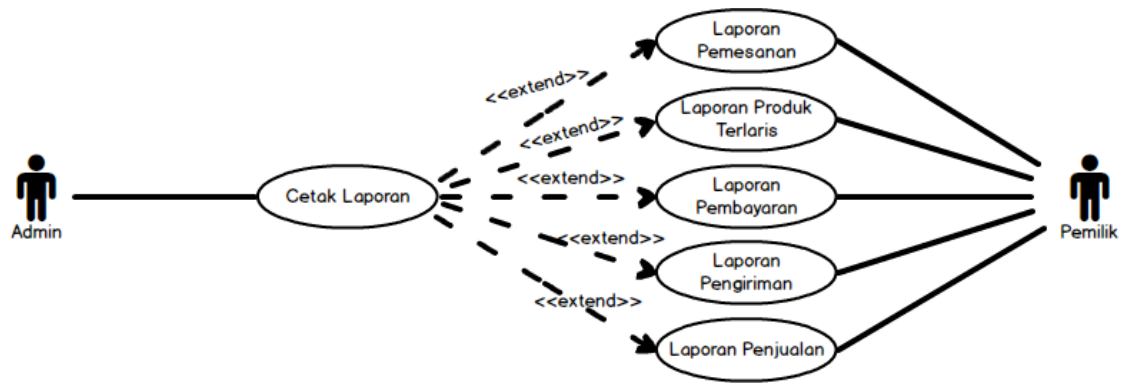

Gambar 6. Use Case Diagram Pembuatan Laporan

Pada Gambar 6 diperlihatkan bahwa beberapa laporan yang disediakan dalam model ini adalah Laporan Pemesanan, Laporan Produk Terlaris, Laporan Pembayaran, Laporan Penjualan, dan Laporan Pengiriman. Aktor yang dapat mengakses fungsi-fungsi ini adalah karyawan dan pemilik toko.

\section{b. Class diagram}

Model struktur data pada sistem e-commerce Asri Konveksi Collection menggunakan class diagram tanpa method. Class diagram tanpa method merupakan model data konseptual yang mirip dengan model Entity Relationship (ER), yaitu model yang hanya memperlihatkan nama kelas, atribut class dan hubungan antar class. Dari Gambar 7 terlihat bahwa untuk pengembangan model sistem e-commerce dibutuhkan duabelas class. Beberapa class untuk menyimpan data data customer, comments, order dan produk. 


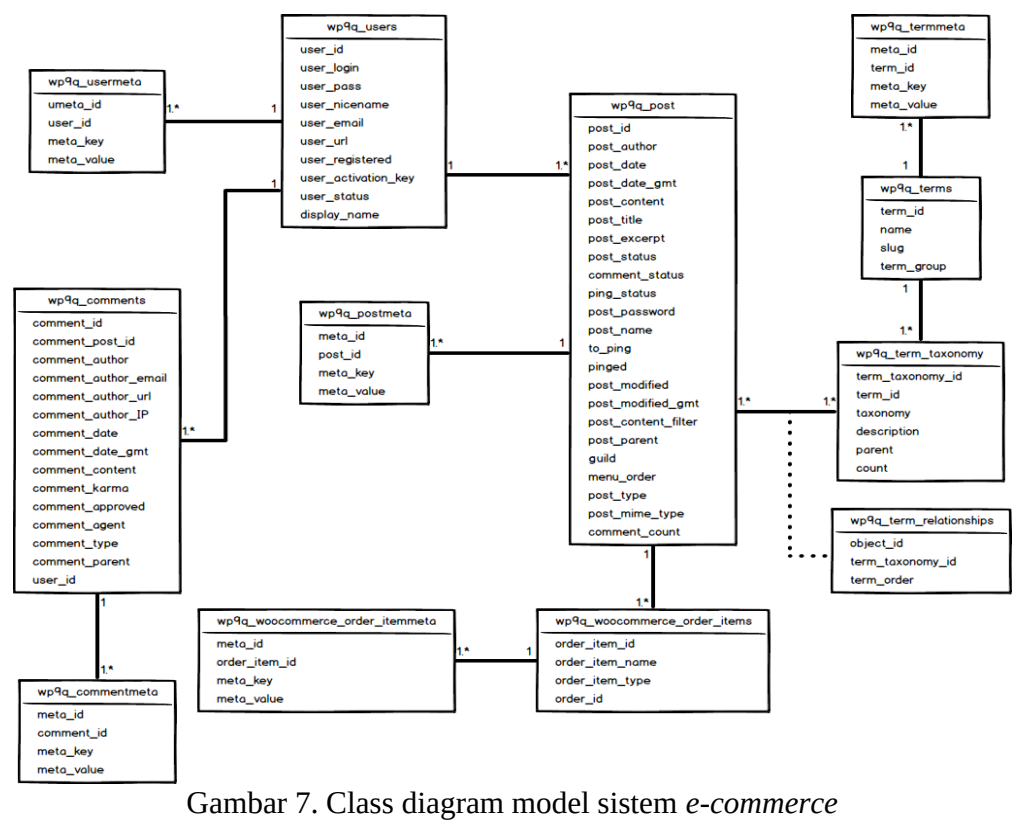

c. Implementasi Model Sistem E-Commerce Asri Konveksi Collection

Model sistem e-commerce berbasis web Asri Konveksi Collection telah diimplementasikan di laman website https://asrikonveksi.com. Tampilan utama dapat dilihat pada Gambar 8.

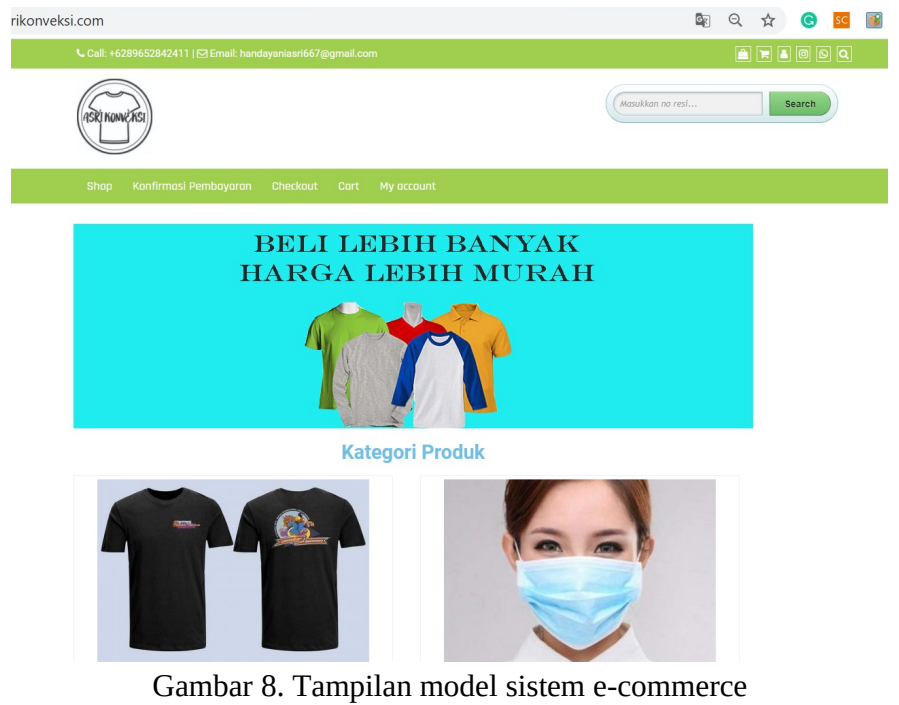

\subsection{Hasil Optimalisasi Sistem}

Upaya meningkatkan kinerja website https://asrikonveksi.com dengan cara SEO. Penerapan SEO ini dapat cepat terindex oleh mesin pencari berdasarkan kata kunci tertentu. Dengan penerapan SEO website yang dikembangkan dapat menembus halaman terdepan di mesin pencari. Strategi SEO yang dilakukan pada website https://asrikonveksi.com adalah strategi on-page dengan memanfaatkan plugin Yoast SEO sebagai salah alat untuk mengoptimalkan keyword, keyphrase atau kata kunci untuk meraih posisi terbaik pada mesin pencari khususnya Google. Hasil dari kinerja Yoast SEO terbukti cukup cepat menempatkan alamat situs di halaman hasil pencarian search engine Google. Hasil dari optimalisasi dapat dilihat pada Gambar 9.

Pada Gambar 9 terlihat bahwa setelah dilakukan optimalisasi, maka posisi pada laman google berada pada halaman ke dua. Website https://asrikonveksi.com pada halaman ke dua dengan menggunakan kata kunci "masker kain polos asri”. Pada pekerjaan ini belum menunjukan hasil yang terbaik, maka dari itu perlu strategi lain yang dapat meposisikan di halaman pertama pada google. 
INDONESIA JOURNAL INFORMATION SYSTEM (IDEALIS)

Volume 4, Nomor 1, Januari 2021

ISSN 2684-7280 (online)

Halaman 37-46

available online at http://jom.fti.budiluhur.ac.id/index.php/IDEALIS/index

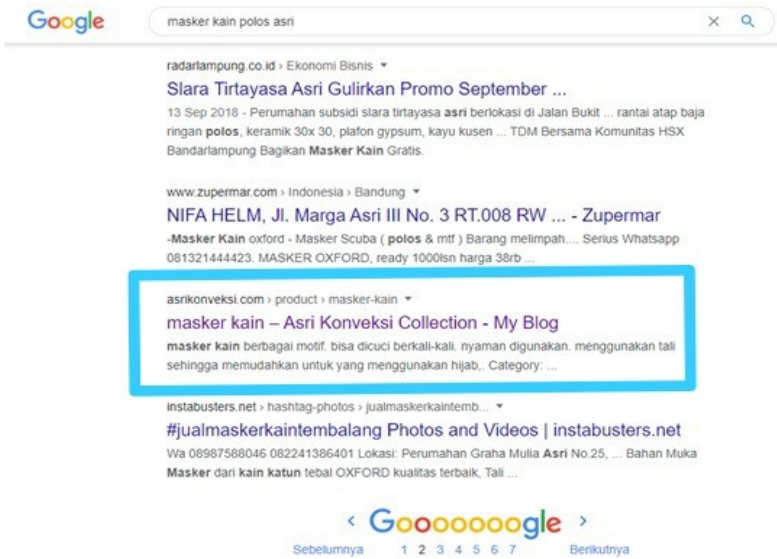

Gambar 9. Hasil dari optimasi

\subsection{Hasil Pengujian}

Pengujian model yang dilakukan adalah pengujian langsung ke user. Pengujian yang dilakukan dibagi menjadi dua tahap, yaitu tahap pertama pengujian terhadap semua fungsi yang ada dan pengujian kedua meminta pendapat atau penilaian dari user. Pengujian pertama adalah mencoba semua fungsi yang ada dengan menggunakan data-data sebenarnya dari dilapangan. Data-data yang digunakan untuk pengujian seperti produk, user dan transaksi yang ada. Pada pengujian ini mendapatkan bahwa semua fungsi yang ada dapat berjalan dengan baik.

Kemudian, pengujian kedua adalah meminta pendapat atau penilaian dari user atau pengguna. Pengujian yang dilakukan adalah mengimplementasikan model di laman web https://asrikonveksi.com dan dimintakan pendapat ke user mengenai model yang dikembangkan. Hasil dari pengujian ini didapatkan bahwa model sistem e-commerce berbasis web yang dikembangkan dapat diterima dengan baik. Dapat diterima dengan baik artinya adalah model yang dikembangkan sudah sesuai dengan kebutuhan user. Model sistem $e$-commerce berbasis web yang dikembangkan dapat menyelesaikan masalah yang ada, walaupun belum sepenuhnya semua masalah dapat diselesaikan. Belum terselesaikannya masalah yang ada karena perlu waktu dalam pengujian dilapangan, yaitu perlu dievaluasi secara rutin kekurangan-kekurangan yang ada.

\section{KESIMPULAN}

Hasil penelitian adalah terbentuknya model sistem e-commerce berbasis web pada Asri Konveksi Collection. Model sistem e-commerce berbasis web yang dikembangkan dapat berfungsi dengan baik dan dapat diterima oleh user dengan baik. Model sistem e-commerce berbasis web yang dikembangkan dapat memberikan kemudahan dalam mengakses informasi barang pada toko Asri Konveksi Collection. Selain itu, model e-commerce yang dikembangkan dapat memperluas jangkauan pasar atau pelanggan. Penggunaan sistem melalui situs web $e$ commerce memudahkan admin dalam mengatur dan mengumpulkan laporan pemesanan, laporan penjualan, laporan pembayaran, laporan pengiriman, laporan stok dan laporan produk terlaris secara daring untuk kemudian diberikan kepada pihak pengelola Asri Konveksi Collection. Dengan adanya fasilitas pembuatan laporan, diharapkan pengelola dapat memanfaatkannya untuk pengambilan keputusan dalam pemasaran dan penjualan.

\section{DAFTAR PUSTAKA}

[1] D. A. D. Nasution, E. Erlina, and I. Muda, “Dampak Pandemi COVID-19 terhadap Perekonomian Indonesia,” J. Benefita, vol. 5, no. 2, p. 212, 2020.

[2] T. Ingmukti and G. Triyono, "Penerapan E-Commerce Dengan Menggunakan Content Management System ( Cms ) Pada Hilookx Hijab,” J. IDEALIS, vol. 2, no. 6, pp. 207-214, 2019.

[3] I. I. Prasetya, and A. Widjaja, "Penerapan E-Commerce Berbasis Wordpress untuk Penjualan pada Distro ID Clothing," IDEALIS: InDonEsiA JournaL Information System, 2(6), 2019, 307-312.

[4] W. A. Putra, and L. L. Hin, "Penerapan E-Commerce untuk Memperluas Jangkauan Pasar Pada Toko Batik Marissa Dengan Menggunakan Metode Business Model Canvas,” IDEALIS: InDonEsiA JournaL Information System, 2(6), 2019, $286-292$.

[5] W. D. Cahyo, and G. Triyono, ”Penerapan E-Commerce berbasis Content Management System (CMS) untuk Penjualan Pakaian Pada Toko Chipindwear,” IDEALIS: InDonEsiA JournaL Information System, 2(6), 2019, 435-411

[6] W. Diphayana, “Perdagangan Internasional.” Yogyakarta: Deepublish, 2018.

[7] N. F. S. Hasyim, “Technopreneurship Membentuk Karakter Entrepreneur Muda Yang Sukses,” Yogyakarta: Deepublish, 2016. 
INDONESIA JOURNAL INFORMATION SYSTEM (IDEALIS)

Volume 4, Nomor 1, Januari 2021

ISSN 2684-7280 (online)

Halaman 37-46

available online at http://jom.fti.budiluhur.ac.id/index.php/IDEALIS/index

[8] H. Himawan, A. Saefullah, and S. Santoso, "analisis dan Perancangan Sistem Informasi Penjualan Online (E-Commerce) pada CV Selaras Batik Menggunakan Analisis Deskriptif,” Scientific Journal of Informatics, 1(1), 2014, 53- 63.

[9] M. Pradana, “Klasifikasi Bisnis E-Commerce di Indonesia,” Modus, 27(2), 2015, 163-174.

[10] A. Osterwalder, and Y. Pigneur, "Business Model Generation: A Handbook for Visionaries, Game Changers, and Challengers," Hoboken: John Wiley \& Sons, 2010.

[11] R. S. Wazlawick, Object-Oriented Analysis and Design for Information Sistems, vol. 4, no. 1. United States of America: Elsevier Editora, 2016.

[12] R. Abdulloh, “Trik Membuat CMS Website Dari Nol,” PT. Elex Media Komputindo, 2016.

[13] G. S. Spais, "Search Engine Optimization (SEO) as a Dynamic Online Promotion Technique : The Implications of Activity Theory for Promotion Managers,” Innov. Mark., vol. 6, no. 1, pp. 7-24, 2010. 